\title{
A GUERRA DO KOSOVO: UMA QUESTÃO HUMANITÁRIA?'
}

\author{
Flávia Rossi \\ Mestranda da USP pelo Programa de Pós-graduação \\ em Integração da América Latina \\ E-mail: flaviarossi@hotmail.com
}

\section{Resumo}

Este artigo diz respeito à guerra do Kosovo e à discussão sobre a questão humanitária a ela vinculada. Procurou-se fazer uma leitura realista da intervenção promovida pela OTAN ao Estado soberano iugoslavo em inícios de 1999, que utilizou-se do discurso de proteção aos direitos humanos da população albanesa-kosovar que vinha sofrendo processos de limpeza étnica pelo governo do presidente Slobodan Milosevic. O principal objetivo deste artigo é mostrar, através do exemplo deste conflito, como os princípios sobre direitos humanos podem ser utilizados como mecanismos que camuflam motivações político-estratégico dos grandes atores estatais internacionais.

Palavras-chave: Kosovo, OTAN, direitos humanos, intervenção

stão se completando três anos do fim do conflito do Kosovo. O tema já teve profundas repercussões na mídia mundial. Hoje, encontra-se quase que esquecido dentro dos veículos midiáticos. Retomando a problemática, com este artigo temos o intuito de fazer um balanço do conflito na Iugoslávia. Também procuramos dar um enfoque à vigente pauta dos direitos humanos dentro das políticas internacionais, através da atual discussão dos instrumentos internacionais

\footnotetext{
1 Este artigo baseou-se na pesquisa monográfica de requisito a conclusão do bacharelado do curso de Ciências Sociais/UFPR, com orientação do Professor Rafael Duarte Villa
} 
legais produzidos na última década, sobretudo a partir da Conferência de Viena de 1993. Neste sentido, buscamos analisar a dinâmica relação entre direitos humanos, presença sérvia na província do Kosovo e a intervenção da OTAN no Estado iugoslavo.

A intervenção tinha a justificativa oficial de deter o genocídio étnico da população kosovar-albanesa promovida pelo então presidente da Iugoslávia Slobodan Milosevic. Antes propriamente, da análise dos fatos que ocorreram a partir da intervenção da OTAN, acreditamos ser necessário dar uma enfoque geral da noção de direitos humanos no âmbito da política internacional com o intuito de situarmonos quanto ao dilema sérvio ante a quebra do princípio de ingerência dos Estados por questões humanitárias bem como ante aquelas questões estratégicas ligadas ao conflito.

Nas relações internacionais, a problemática dos direitos humanos encontra uma limitação nos direitos do Estado em relação aos seus cidadãos. Isso é o mesmo que dizer que, nas relações internacionais, a questão dos direitos humanos encontra seu limite na soberania estatal. No sentido hobbesiano, a soberania se estabelece como uma maneira de extinguir a anarquia do Estado de Natureza no território do Estado. No território interno do Estado, a todos e a cada um é aplicado o direito que tem como única fonte o Estado. Todos os cidadãos estão sujeitos ao monopólio estatal da força e da aplicação do direito.

De acordo com Lafer (1995, p.141)., os direitos humanos representam, no plano jurídico, uma inversão da figura deôntica originária, ou seja, significam uma passagem do dever do súdito para o direito do cidadão [...]. São as Declarações que criam [...] o direito do indivíduo a ter direitos, pois partem do pressuposto de que a pessoa humana tem uma dignidade e uma singularidade que não se dissolve no todo da boa gestão da comunidade política . Nessa perspectiva a concepção realista de Estado se encontra limitada, visto que o indivíduo não é para o governo, e sim o governo é para o indivíduo. Há a partir de então uma ligação mais direta entre ética no plano interno, da democracia e dos direitos humanos, e a paz e a dignidade no plano internacional.

Tratar os direitos humanos como tema global significa remeterse ao campo de valores no qual a violação de tais direitos atinge a soberania popular comprometendo a perspectiva dos governados. Em 
outras palavras, a associação entre democracia e direitos humanos significa que existe uma relação entre o ciclo do poder e a justiça da norma, na qual a legitimidade do poder e a justiça da norma e de sua aplicação representam o terreno comum entre princípios éticos e prática política no plano interno (LAFER, 1995).

Enquanto no século XIX a evolução dos direitos civis e políticos deram-se mais no plano interno dos Estados a partir de um constitucionalismo liberal, na esfera internacional eles limitaram-se ao princípio do dever de intervenção, à regulamentação jurídica da violência e à abolição da escravidão. Isso é o que se conhece como primeira geração de direitos humanos no âmbito internacional. Já no século XX outras questões foram postas em pauta, como a proteção internacional às minorias, a autodeterminação dos povos, o tratamento igualitário, a tutela de refugiados pela Sociedade das Nações na década de 20 e 30, assim como preocupações da OIT com os assalariados. Essas questões buscaram limitar as soberanias através de um direito internacional, e também constitucionalizar as relações internacionais. A emergência desses direitos correspondem a uma segunda geração de direitos humanos no sistema internacional.

Em 1948, a Declaração Universal dos Direitos Humanos feita pela ONU buscou combater as atrocidades cometidas até então, através da implantação de um mecanismo de segurança que permitisse o reconhecimento do direito à hospitalidade universal, a descolonização dos povos e o direito ao desenvolvimento. Dessa forma originava-se uma nova (terceira) geração de direitos.

Essas três gerações de direitos humanos, na ordem internacional, são marcadas por uma seletividade de interesses feita pelas nações mais poderosas. Já é sabido que os Estados Unidos apegam-se mais aos direitos da primeira geração, visto que dizem respeito às idéias liberais da democracia americana - ao contrário dos direitos da segunda geração, que se baseiam nos direitos econômicos e sociais advindos dos ideais de igualdade defendidos pelas lutas socialistas na Europa. Evidentemente esses direitos eram mais reivindicados pela União Soviética. Isso levou a uma polaridade de interesses que dificultaram a prática da interdependência das três gerações de direitos. Tratar os direitos humanos como tema global significa que as soberanias devem submeter-se à agenda 
internacional não alegando princípios de não-ingerência determinados por questões que dizem respeito às soberanias dos Estados .

Em relação ao tema dos direitos humanos, a Conferência Mundial de Direitos Humanos, realizada em Viena em junho de 1993, foi um marco de grande importância. A Declaração de Viena se consolidou como o documento mais abrangente adotado pela comunidade internacional sobre o tema. Ela definiu o caráter universal dos direitos humanos, assim como a necessidade de interdependência entre democracia, direitos humanos e desenvolvimento, objetivando o progresso das nações e da paz. A democracia, afirma Lindgren Alves, é um valor histórico e ao mesmo tempo universal.

A Declaração de Viena atribuiu à democracia a condição de regime político mais favorável à consolidação e à proteção dos direitos humanos, e também colocou-a como um tema global, ou seja, os direitos humanos passam a viger em um plano de maior abrangência, no qual existiriam mecanismos internacionais efetivos de alto controle na garantia desses direitos, ultrapassando inclusive a competência reservada às soberanias dos Estados.

Segundo Celso Lafer o reconhecimento dos direitos humanos como tema global significa a convergência e a complementaridade entre ética e política, tornando a legitimidade dos governos, no plano mundial, condicionada à vigência de mecanismos e garantias dos direitos fundamentais (apud BENEVIDES, 1994, p.182).

Um tema polêmico dos direitos humanos refere-se à oposição entre universalidade e relativismo cultural. A universalidade, acusam certos países, principalmente asiáticos, africanos e de religião islâmica, é uma tentativa de dominação cultural de Ocidente. Assim o cultural, pode significar uma proteção às minorias, mas também, ao contrário, uma apatia relativamente a costumes que agridem a dignidade do ser humano. Desta forma, a oposição entre universalidade dos direitos humanos e a soberania nacional gera polêmica. A Conferência de Viena declarou que a natureza universal de tais direitos não admite dúvidas e que as particularidades históricas, culturais e religiosas devem ser levadas em consideração, mas os Estados têm o dever de promover e de proteger todos os direitos humanos, independente dos respectivos sistemas (ALVES apud BENEVIDES, 1994, p.176). 
A Declaração de Viena também tocou no polêmico tema da relação entre direitos humanos e soberania estatal. Isso ficou evidente no reconhecimento da legitimidade da preocupação internacional com a promoção e a proteção dos direitos humanos (Artigo 4). Assim, reconhece-se, embora isso ainda seja polêmico, que os direitos humanos ultrapassam o domínio reservado aos Estados. Estes, por sua vez, ficam impedidos de usarem certos recursos abusivos do conceito de soberania para praticarem violações.

Embora consagrados na Conferência de Viena de 1993 como de caráter universal, os direitos humanos passam - de acordo com Lindgren Alves (1995, p.150) - por um retrocesso nos acordos definidos. Certos governos voltaram a questionar a legitimidade da ordem internacional em relação ao tema, por julgarem- nos como direitos ocidentalizados. Também verifica-se o grande crescimento dos fundamentalismos: religiosos, nacionalistas, étnicos, raciais, xenófobos, econômicos e comportamentais, de maneira que não há dúvidas de que a vertente integrista desta 'pós-modernidade' tende a banalizar-se pelo sepultamento da razão Iluminista. Nesse ponto, a razão kantiana de uma sociedade cosmopolita, de condições de paz perpétua advinda da racionalidade do homem livre, perde o sentido e deixa livre o caminho para a alternativa das soberanias hobbesianas.

A $51^{a}$ Sessão da Comissão dos Direitos Humanos das Nações Unidas, realizada em 1995, mostrou a pouca adequação efetiva de meios e modos que desenvolvem a causa dos direitos humanos na atualidade. No contexto de mais de trinta conflitos sangrentos, o caso de Ruanda em 1994, onde um milhão de pessoas morreram em apenas seis semanas, tornando-se assim o recorde mundial de genocídios por hora, exemplifica a inadequação de meios da comunidade internacional para lidar com a causa, dispondo apenas de um relator na região para monitorar a situação do país. Afirma Lindgren Alves (1995, p.160), é difícil imaginar, à luz das tendências concretas da história contemporânea, que a real situação dos direitos humanos no mundo possa corresponder aos propósitos e às recomendações das conferências das Nações Unidas. Estas têm podido manter, até agora, não sem dificuldades, o sentido de progresso racional que deve permear os esforços para a construção de uma realidade mais justa, nas esferas nacionais e internacional. Correm, porém, o risco de 
permanecer no nível do discurso face ao irracionalismo regressivo que vem caracterizando uma vertente importante da 'pós-modernidade'.

A partir desse panorama normativo, a problemática dos direitos encarou um teste importante na guerra do Kosovo. Entretanto, a compreensão dessa problemática requer de nossa parte, no mínimo, um certo olhar histórico retrospectivo a fim de compreendermos melhor os encontros e desencontros daqueles no mundo dos interesses estatais internacionais.

\section{Sérvia e Kosovo na História}

A problemática da Sérvia e do Kosovo tem suas raízes num contexto histórico marcado por guerras e conflitos territoriais entre povos de diferentes nacionalidades. No século XX, Kosovo, que se situa na região dos Balcãs, foi reconhecido internacionalmente como parte da Sérvia e também da Iugoslávia. A região é um território soberano e juridicamente inviolável. No entanto, um dos principais problemas é que a maioria das pessoas que vivem no local, de origem albanesa, não querem fazer parte da Sérvia. ${ }^{2}$

Durante a Idade Média, povos eslavos vindos da Rússia estabeleceram-se na região dos Bálcãs e entre os séculos XI e XV Kosovo foi o centro do Reino sérvio, ocupado por uma população de maioria eslava e de religião cristã-ortodoxa. No entanto o Reino sérvio seria, em finais do século XIV, absorvido pelo impressionante avanço turco-otomano. Em 1389, na Batalha dos Melros Negros, os turcootomanos expandiram seu império derrotando os sérvios e conquistando o Kosovo.

No século XVIII, toda a península balcânica, do mar Egeu e dos estreitos turcos até as fronteiras dos impérios russo e austro-húngaro, haviam sido, com algumas exceções, abarcada pelo Império turco. Esse domínio se prolongaria até o início do século $\mathrm{XX}$, quando os turcos foram obrigados a retirar-se de grande parte da região, restando-lhes

\footnotetext{
${ }^{2}$ Em inícios do século $\mathrm{XX}$, a população albanesa representava $90 \%$ da população do Kosovo, enquanto os sérvios caíram na composição populacional para apenas $10 \%$.
} 
apenas o sul da península, principalmente a Trácia e a Macedônia. Esse acontecimento fez com que no século XX surgissem vários Estados libertados do antigo Império, como a Bulgária, a Sérvia, Montenegro e a Romênia. Esses países eram monarquias, mas suas dinastias não se encontravam bem definidas. Seus poderes, em geral, eram governados administrados por organismos parlamentares inexperientes e indisciplinados, não sendo as igualmente bem definidas nem plenamente aceitas. Era uma região de pouca estabilidade internacional e institucional (KENNAN, 1993).

Durante quase cinco séculos a Sérvia foi dominada pelos turcos otomanos que reprimiram todos os povos eslavos sob seu domínio. Assim, o domínio turco serviu para sedimentar o espírito nacionalista dos sérvios, além de fazer emergir um impressionante espírito guerreiro. A Sérvia conseguiu sua independência do Império Otomano em 1878 e iniciou as Guerras Balcânicas em 1912 contra a Turquia, conseguindo reconquistar a região do Kosovo.

Em meio a esses acontecimentos, cresciam os nacionalismos, típicos da época, principalmente na região dos Bálcãs. A expansão territorial tornou-se o objetivo de vários desses países nascentes: consolidou-se o desejo de uma Sérvia maior, uma Bulgária maior, e assim por diante. A Turquia passou a ser vista como a doente da Europa e requeria-se uma aliança para uma ação conjunta. Unamo-nos para completar a expulsão dos turcos passou ser a palavra de ordem. Ou cada um terá o que lhe pertence. Pensamentos como este levaram os sérvios, búlgaros, gregos e montenegrinos a realizarem um ataque militar conjunto contra os turcos no ano de 1912. Os turcos foram derrotados em poucas semanas de guerra e o resultado foi a ocupação de partes da Macedônia por tropas da Sérvia, da Bulgária e da Grécia. Seguidamente, em 1913 iniciou-se a Segunda Guerra Balcânica entre essas três aliadas que buscavam agora, cada uma delas, o domínio da Macedônia. Todavia, o conflito entre esses países não nasceu no século XX: já que Sérvia e Bulgária eram antigas rivais que buscavam dominar a região sul dos Bálcãs. O conflito, bastante violento, acabou com a derrota da Bulgária, tendo este país que assinar o Tratado de Paz de Bucareste em 10 de agosto de 1913, pelo qual a Macedônia foi repartida entre aqueles três países. 
É neste contexto histórico de guerras nacionalistas que se localiza o conflito do Kosovo. É importante relembrar que, a partir da tomada da região do Kosovo pelo Império turco (1453), os sérvios de religião cristã-ortodoxa começaram a migrar para o norte e os albaneses de religião muçulmana aumentaram sua presença em Kosovo. Sua migração foi tão maciça que, em inícios do século $\mathrm{XX}$, a população albanesa representava $90 \%$ da população do Kosovo, enquanto os sérvios tinham caído na composição populacional para apenas $10 \%$. Neste desequilíbrio populacional, que levou os sérvios a transformaremse em uma minoria no Kosovo, um aspecto cultural é marcante: é no Kosovo que os sérvios, de religião ortodoxa cristã, têm quase $50 \%$ de seus templos e igrejas ainda nos nossos dias. Esse fator é importante para a compreensão de que o problema do Kosovo não pode ser visto simplesmente como uma reivindicação de natureza territorial. Trata-se também de um conflito de natureza cultural que se encaixa bem no que Huntington chama de choque de civilizações: a política mundial está sendo reconfigurada seguindo linhas culturais e civilizacionais. Neste mundo, os conflitos mais abrangentes, importantes e perigosos não se darão entre classes sociais, ricos e pobres, ou entre outros grupos definidos em termos econômicos, mas sim entre povos pertencentes a diferentes entidades cùdturais [...]. Nesse mundo novo, política local é a política da etnia e a política mundial é a política das civilizações. A rivalidade das superpotências é substituída pelo choque das civilizações (HUNTINGTON, 1997, p.21).

José Chiappin Novaes em artigo intitulado O paradigma de Huntington e o realismo político faz uma crítica ao paradigma do choque de civilizações de Huntington afirmando que este paradigma não passaria de uma simples e nova versão do realismo: Huntington ao afirmar que as novas unidades não são apenas os estados nacionais mais comunidades, aldeias, cidades, grupos, civilizações, não está desafiando a concepção geral do realismo político [...] Pode-se afirmar que o paradigma não apresenta nenhuma revolução profunda com respeito ao realismo político. Uma análise mesmo superficial dos seus textos sobre o paradigma das civilizações mostra que a sua linguagem, o seu sistema teórico, as suas avaliações e recomendações são típicas daquelas do realismo político (CHIAPPIN NOVAES, 1994, p.52-53). 
Essa tese de Huntington, dos choques de culturas, coloca uma ênfase na questão nacionalista, da qual o conflito do Kosovo é um excelente exemplo. Segundo George Kennan, esse nacionalismo dos Bálcãs, do modo como se manifestou no campo de batalha, provinha de traços mais profundos de caráter presumivelmente herdado de um passado tribal distante: uma tendência a encarar, de modo geral, o de fora com grande desconfiança e o adversário político-militar, em particular, como um inimigo temido e implacável que só se pode tornar inofensivo pela destruição total e impiedosa. E continua a ser assim nos dias de hoje [...]. Diante da extrema auto-admiração nacionalista e da desconfiança em relação a qualquer dos vizinhos, havia pouco espaço para o que quer que se parecesse com reconciliação (KENNAN, 1993, p.79).

$\mathrm{Na}$ Segunda Guerra Mundial o país é invadido pela Alemanha e a dirigência política croata decide formar um Estado independente aliado ao nazismo. É então quando surge a figura de Josip Broz Tito, uma liderança comunista de origem croata que reorganizou o país tornando a Iugoslávia uma federação de seis Estados: Sérvia, Croácia, Eslovênia, Bósnia-Herzegovina, Montenegro e Macedônia e duas províncias autônomas: Kosovo e Voivodina (ambas vinculadas à Sérvia). Durante o governo de Tito que se estendeu até 1980, a Iugoslávia é comandada por uma comunismo independente ou não alinhado ao modelo soviético, o que de alguma maneira transforma Tito numa das lideranças do movimento dos não alinhados junto com a Índia, Egito e Cuba.

O antagonismo e o ódio entre os povos que compunham a Iugoslávia aparecem novamente após a morte de Tito em 1980. Sete anos após a morte de Tito, o então líder do partido comunista, Slobodan Milosevic tenta impor o domínio sérvio sobre o resto dos povos da Iugoslávia. Uma das primeiras medidas de Milosevic consistiu em retirar a autonomia do Kosovo concedida durante a era Tito. O novo governante, Milosevic, de origem sérvia, coloca a construção de uma Sérvia maior sobre as ruínas da Iugoslávia de Tito. Neste quadro, reaparecem as diferenças étnicas (principalmente dos sérvios em relação à croatas, mulçumanos e kosovares). Essas diferenças eram acompanhadas pelas aspirações de uma política nacionalista que acabou formando verdadeiros chauvinistas por toda região dos Bálcãs. 
A partir de 1989, o governo de Milosevic extingue a autonomia da província de Kosovo e inicia um processo de limpeza étnica com perseguições e violações dos direitos humanos do povo kosovaralbanês. Kosovo ainda tinha quase $90 \%$ de sua população de origem albanesa. Em 1995 é assinado por Milosevic o Tratado de Paz em Dayton, mas Kosovo ficou fora do tratado, não recuperando sua autonomia dos tempos de Tito. Dessa maneira, o mundo ocidental reconheceu explicitamente a nova República Federal da Iugoslávia compondo as fronteiras com a Sérvia e Montenegro com Kosovo fazendo parte da Sérvia (ver mapa).

Nos anos seguintes ao acordo de Dayton, os kosovares albaneses começaram a receber fundos e armas através de seu país territorial e culturalmente vizinho, a Albânia consolidando uma estrutura militar na figura do Exército de Libertação do Kosovo (EKL). Em 1998 iniciam-se conflitos entre o EKL e forças do exército sérvio que causaram um verdadeiro holocausto na região $\mathrm{O}$ parlamento europeu abriu um debate em 14 de abril de 1998 condenando unanimemente o governo de Milosevic. Essa unanimidade se manteve quando se tratava da exclusão da intervenção militar como meio legítimo, mas desaparecia quando se tratava de outros meios a se utilizar para punir os crimes contra a humanidade, que estavam sendo comandados por Milosevic. Apesar de os kosovares aceitarem a proposta de manutenção de sua autonomia permanecendo formalmente como parte integrante da Iugoslávia, Milosevic não aceitou e continuou sua ofensiva em Kosovo.

\section{Os antecedentes imediatos da intervenção da OTAN: de Dayton a Raoumbuillet}

A exclusão do Kosovo no acordo de Dayton em 1995 acabou por intensificar os conflitos no Kosovo bem como intensificou o desenvolvimento da crise para um caráter internacional. O problema se encontrava na falta de status da região no âmbito dos acordos de Dayton. Esses acordos não precisam estritamente se o Kosovo é um território soberano da Sérvia ou se é uma região autônoma. A omissão do Grupo 
de Contato (formado por representantes dos Estados Unidos, Europa Ocidental, da ONU, da Iugoslávia e dos kosovares albaneses) acerca do futuro do Kosovo enfraqueceu a possibilidade de uma solução política negociada que devolvesse a autonomia da província através da mediação internacional. Assim, o governo de Milosevic tratou de garantir que a jurisdição do Kosovo fosse de competência interna da Iugoslávia. Com a violência se agravando na região, era contraditória a política de manutenção do status quo obtido em Dayton e a defesa dos direitos humanos, civis e políticos da população albanesa no Kosovo. Então, Rambouillet surgiu como o acordo que deveria resolver as pendências de Dayton evitando assim a guerra e restaurando a autonomia do Kosovo. No entanto, esse período anterior à deflagração do conflito militar gerou um intenso debate sobre a eficácia ou não dos acordos de Rambouillet. Noam Chomsky (1996, p.60) faz uma das críticas mais freqüentes à intervenção no Kosovo. No dizer do autor: "É inteiramente possível que um ataque aos sérvios que se consideram a parte lesada, poderia inspirá-los a entrar mais agressivamente em Kosovo, na Albânia, o que poderia desencadear uma grande guerra, envolvendo a Grécia e a Turquia".

Apesar do diagnóstico de Chomsky não se ter cumprido no todo, é notória a maneira como o pensador americano, de alguma forma, já advertia sobre a pouca eficácia dos bombardeios. Para o autor, os Estados Unìdos e a União Européia pouco se empenharam em buscar a paz em Rambouillet. Desde o início, os EUA apostavam no fracasso da conferência a fim de iniciar os ataques à Iugoslávia. Na realidade, o lado iugoslavo estava disposto a aceitar as condições políticas do acordo, ou seja, a devolução da autonomia de Kosovo, mas as cláusulas militares, que incluíam a ocupação da região por efetivos da OTAN, eram tão abrangentes que sua aceitação equivalia à renúncia, de fato, à soberania da Iugoslávia sobre a totalidade de seu território

Numa crítica posterior, para J. Pontes Nogueira (2000), o raciocínio de Noam Chomsky é muito simplista, não abrange toda a complexidade das negociações. Para ele, existem questões-chave de extrema importância nas negociações em Rambouillet: o fim da repressão à maioria albanesa, a retirada das forças regulares e paramilitares sérvias e o envio de uma força de paz para garantir a implementação do acordo: 
e finalmente, o status futuro do Kosovo dentro da Federação Iugoslava. Apesar de quaisquer pendências, o acordo foi de grande importância, pois recuperava a autonomia político-administrativa da região.

Outros observadores da política internacional, como Robin Blackburn, alegam que a conferência foi um fracasso devido à intransigência ocidental sobre os aspectos militares do acordo. Os Estados Unidos determinavam que a força de paz que monitoraria a região seria comandada por efetivos da OTAN; por outro lado, a Iugoslávia, com o apoio da Rússia, aceitaria uma força multinacional sob o amparo da ONU. Blackburn considera que as determinações militares do tratado foram, de fato, inaceitáveis para a Sérvia. $\mathrm{O}$ ataque à Iugoslávia teria como principal motivo a inclusão dos Bálcãs e de toda a Europa Central à esfera de influência da OTAN iniciado no processo de expansão do pós-guerra fria (BLACKBURN apud NOGUEIRA, 2000).

Contráriamente a essa análise, o que realmente estava em questão não era se os efetivos estariam sob o comando da OTAN, ou da ONU ou da Organização de Segurança e Cooperação Européia (OSCE). Os sérvios não aceitavam de forma alguma a presença de uma força internacional no Kosovo. O máximo que era aceitável por eles, era a presença de observadores desarmados da OSCE ou os peacekeepers da ONU. Estava claro que, para o sucesso do acordo de Rambouillet, seria necessário que os albaneses renunciassem a sua reivindicação de independência e que o governo iugoslavo aceitasse a internacionalização do problema de Kosovo através da presença de forças da OTAN. Pontes Nogueira aponta o fato de que era preferível que uma força internacional com o amparo da ONU ou da OSCE (a Rússia, desta maneira, participaria do processo) do que a OTAN nos processos de implementação dos acordos. Porém, os Estados Unidos argumentavam que, devido a experiência da Bósnia, se tornava claro que uma força da OTAN seria mais eficaz do que a ONU ou a OSCE (NOGUEIRA, 2000). Como Kosovo é o mito fundador da nacionalidade sérvia, a possível perda do controle da região representaria um extremo golpe na estrutura de poder construída por Milosevic e seus aliados nos últimos anos desde os processos de expansão iniciados em 1991. Assim era praticamente inaceitável a presença militar estrangeira, seja lá qual fosse essa força. 
Com a intensificação do processo de limpeza étnica da população albanesa-kosovar, em finais de 1999 comandado pelo então presidente Slobodan Milosevic e pelo nacionalismo ortodoxo iugoslavo, a OTAN decidiu intervir militarmente na região em março de 1999. Porém, suas justificativas baseadas na proteção dos direitos humanos da população albanesa massacrada foram postas em dúvida. Junto a isto, também se questionou a unilateralidade e a legitimidade da decisão de intervir feita pela mesma, ou seja, o fato dela ter sido tomada por uma organização de segurança regional, sem a autorização do Conselho de Segurança da ONU.

O tema da legitimidade da ação da OTAN na Iugoslávia até hoje é objeto de árdua polêmica por isso, antes de analisarmos as motivações propriamente dita dos atores internacionais no conflito, é cabível fazer algumas observações referentes à contextualização do papel dos organismos internacionais a fim de situarmos a importância destes agentes como atores não-estatais do pós-guerra fria.

Segundo Samuel Pinheiros Guimarães, as transformações do pós-guerra fria permitiram a redefinição das funções de instituições intergovernamentais políticas e de segurança mundiais e regionais. Como atenta o autor, "na área política, a estratégia é definir e negociar compromissos internacionais que incorporem regras de bom governo - good governance - a serem seguidas pelos países periféricos, tais como a adoção da democracia representativa como único regime aceitável de governo; controle da corrupção; direitos humanos e minorias legislação social e trabalhista; política de meio ambiente e desarmamento nuclear e convencional. Essas normas seriam sancionadas através de organismos regionais ou de organismos multilaterais" (GUIMARÃES, 1999, p113-114). Especificamente, como salienta Villa: Hoje em dia, para cada área importante da política mundial, existem instituições especializadas que asseguram um mínimo de governabilidade internacional ou de good governance $\mathrm{O}$ campo da segurança internacional estratégico vem sendo assumido de maneira mais atuante pelo Conselho de Segurança da ONU e pela OTAN; o campo financeiro pelo Fundo Monetário Internacional e pelo Banco Mundial; a área comercial pela Organização Mundial do Comércio, e a área político-diplomática pelo chamado G-7 (VILLA DUARTE, 2000). 
É dentro desse quadro de especialização institucional mundial da política sublinhado por Guimarães e Villa que se insere a ação da aliança do Atlântico Norte na Iugoslávia. A OTAN, enquanto instituição especializada em segurança internacional, no âmbito da ONU, violou as cláusulas do direito internacional que regulam as intervenções internacionais. Isto porque o Conselho de Segurança da ONU é formado por aproximadamente vinte membros que possuem autonomia em relação à Assembléia Geral da ONU tendo poder de veto apenas os Estados Unidos, a China, a França, a Inglaterra e a Rússia, ou seja, as decisões a serem tomadas no Conselho, dependem do consenso destes cinco membros permanentes. Segundo o Estatuto do Conselho de Segurança, quando algum desses membros veta uma moção através do seu voto contrário, esta não poderá ser aprovada.

A questão da legitimidade da ação da OTAN se levantou porque, mesmo com o poderio da organização, ela não estaria respaldada e referendada por uma organização como a ONU e seu Conselho de Segurança que, ao menos formalmente, representa interesses da comunidade internacional. Mas é importante ressaltar que, se por um lado, a intervenção na região mostrava a ilegitimidade de atuação da OTAN perante a ONU, ao votarem Rússia e China votariam contra no Conselho de Segurança, por outro, formalmente não existe uma hierarquia de poder que possa fazer uma organização internacional subordinar-se à outra, ao passo que a OTAN e a ONU, ambas organizações internacionais, detêm autonomia de ação. Assim, a OTAN, sob a hegemonia americana, pode eximir-se da consulta ao Conselho de Segurança e iniciar os bombardeios na região.

Assim, partindo das dúvidas produzidas pela ação da OTAN e pelas justificativas dela decorrentes, procuramos detectar reais as motivações dos atores internacionais no conflito.

\section{A motivação das potências no conflito: OTAN/Rússia/China}

As árduas críticas à OTAN pela ausência de legitimidade internacional na intervenção e pelo desrespeito à soberania estatal 
iugoslava terminaram por acusar os Estados Unidos de pretenderem tornar-se os policiais do mundo . A intervenção promovida pela OTAN no Kosovo, baseada em justificativas de natureza moral de proteção aos direitos humanos da população albanesa-kosovar. foi usada como escudo argumentativo para a intervenção na região. De acordo com o raciocínio realista das relações internacionais, não são legítimas as justificativas de intervenção baseados em questões éticas. Para o realismo, o Estado é o mais importante e básico ator das relações internacionais. A teoria realista vai ao encontro daquilo que Bedin denominou de estadocentrismo (BEDIN, 2000) e parte do pressuposto de que, apenas os Estados são atores das relações internacionais porque só eles possuem poder soberano sobre um território.

De maneira sintética, segundo Robert Keohane, o realismo das relações internacionais se sustenta em três pressupostos básicos:

1) O argumento centrado no Estado: os Estados são os agentes mais importantes na política mundial;

2) A questão da racionalidade: a política mundial pode ser analisada como se os Estados fossem agentes racionais unitários, que calculam cuidadosamente os custos dos cursos de ação alternativos, buscando levar ao máximo e sem ter, necessariamente, suficiente informação sobre as alternativas ou os recursos ( tempo ou outro) para realizar uma revisão plena de todos os cursos de ação possíveis;

3) O pressuposto do poder: os Estados buscam o poder (tanto a capacidade de influenciar os demais como os recursos que se podem usar para exercer influência) calculando seus interesses em termos de poder, seja como fim seja como meio necessário para uma variedade de outros fins (KEOHANE, 1993).

Contrapondo- se a Keohane, um outro autor, Vigevani, faz uma crítica a esta teoria ressaltando o surgimento de um conceito de interdependência entre diversos atores do sistema internacional (estados, corporações multinacionais, bancos, ONGs transnacionais e organizações internacionais). Esta crítica acaba relativizando o papel do Estado enquanto ator único do sistema internacional. A este respeito o autor afirma que essa ampliação ou mudança significou uma 
perda parcial por parte do Estado de seu status de ator dominante, e praticamente único da política internacional: seu 'poder' foi debilitado pelo surgimento de novos atores internacionais . (VIGEVANI, 1994, p.16). No mesmo sentido, Mariano e Mariano também fazem uma crítica afirmando "A perspectiva realista proporciona maiores dificuldades para analisar as mudanças acontecidas na política mundial atual, principalmente quando o foco é a ascensão das relações transnacionais e o surgimento de novos atores no sistema internacional" (MARIANO; MARIANO, 2001). Porém, Vigevani (1994, p.16) é cauteloso ao afirmar todavia, apesar da existência dos novos atores não-estatais, são os governos nacionais que controlam e regulam as relações transnacionais e interestatais .

Contrariamente à perspectiva idealista - que acredita que a intervenção no Kosovo respondia a uma motivação que procuraria preservar os direitos humanos da etnia kosovar - na perspectiva realista, é possível construir motivações latentes na ação política e nas escolhas dos principais atores envolvidos no conflito.

Seguindo esse raciocínio, Cavagnari Filho (1999, p.7)- destacado intelectual realista brasileiro - explica que, na guerra de Kosovo, a solução militar para o conflito não foi uma intervenção que visava apenas questões humanitárias induzidas pelo dever de ingerência . Na verdade, o discurso do dever de ingerência contrariava os princípios da soberania nacional e da não-intervenção ${ }^{3}$. Além de questões humanitárias, as grandes potências integrantes da OTAN tinham o objetivo implícito de submeter a Sérvia aos termos de Rambouillet ${ }^{4}$ e tencionavam também reduzir o protagonismo futuro da Rússia e da China garantindo - através dos bombardeios contra a Iugoslávia - a credibilidade futura da OTAN necessária para intervir em possíveis conflitos. Este argumento pode ser visto como tipicamente de filiação realista. Nele a noção de intervenção humanitária dificilmente é constituída de uma motivação que tem por fundamento elementos essencialmente humanitários. Nessa perspectiva, os Estados são

${ }^{3} \mathrm{O}$ direito de ingerência por razões humanitárias havia sido formalizado no início dos anos 80, pela ONU.

${ }^{4}$ Pôr fim à repressão aos albaneses de Kosovo, retirar as forças regulares e paramilitares sérvias, enviar uma força de paz para garantir a implementação do acordo e garantir o status futuro do Kosovo dentro da Federação Iugoslava. 
monstros leviatânicos frios e calculistas que medem sua ação de acordo com o critério de custos e benefícios. Os direitos humanos são instrumentalizados como justificativas de outros tipos de motivação. No caso do conflito do Kosovo, ele seria um teste decisivo de fortalecimento da Aliança Atlântica na medida em que revelasse sua eficácia ofensiva e sua tentativa de limitar a influência russa na Europa Oriental. Para a OTAN e os Estados Unidos, o significado políticoestratégico da vitória em Kosovo seria a consolidação da superioridade da OTAN no campo da segurança européia, visto que a região é um caldeirão de nacionalidades e é estratégica, pois faz ponte entre a Ásia e a Europa. Além disso os Estados Unidos a aspiram novas adesões advindas da região - como os ex-satélites soviéticos (Tchecoslováquia, Romênia, Hungria, Polônia).

Mas para outros países que se inseriram no conflito também é possível perceber certos motivos não declarados: a Rússia, além de manter laços históricos com os sérvios e de terem problemas similares com povos muçulmanos (caso da Tchetchênia), pretendia, assim como os Estados Unidos, marcar presença numa região estrategicamente importante. A região, que engloba Europa Oriental, Ásia Central e Rússia, como já compreendia o geógrafo inglês Alfred MacKinder no início do século XX, é de fundamental importância. Seu objetivo consistia em poder alertar as elites políticas ocidentais, especialmente as inglesas, sobre a privilegiada posição geoestratégica de quem dominasse essa imensa massa terrestre. Como no início do século, a maior parte dessa massa estava dominada pela Rússia, MacKinder se preocupava com a possibilidade de que uma aliança russo-alemã pudesse desequilibrar a balança de poder no velho continente, balança que havia garantido a governabilidade internacional desde o início do século XIX. MacKinder sintetizou assim seu temor na conhecida fórmula: Quem domina a Europa Oriental controla o Heartland; quem domina o Heartland controla o World Island ${ }^{5}$; quem domina o World Island controla o mundo (MACKINDER apud MELLO, 1999, p.50).

\footnotetext{
" A World Island é outro conceito mackinderiano, que rejeita a idéia tradicional de que possam existir quatro oceanos e seis continentes. Segundo a idéia de MacKinder existia na verdade só um grande oceano, cujas águas recobririam três quartos da totalidade do globo. A isso o geógrafo inglês chamou de World Island (Ilha mundial).
} 
Sob essa perspectiva geopolítica é compreensível que os acontecimentos numa região como a Iugoslávia, que forma parte também da Europa Oriental, possa ter reflexos ou projeções sobre aquelas regiões da Ásia Central como a Tchetchênia. Os conflitos de ordem cultural e também de natureza militar podem não só desequilibrar uma certa balança de poder cultural mas podem também ter seus efeitos geoestratégicos num longo prazo. Assim não é desprezível a idéia de que um controle ocidental da região do Kosovo por parte da força da OTAN possa vir a afetar o funcionamento normal dos imensos oleodutos russos que atravessam parte da Ásia Central (como a própria Tchetchênia) e que chegam até a Turquia. Isso já vem sendo alertado por alguns analistas internacionais: [...] existem outros interesses em jogo, interesses de alcance mais longo. Trata-se da velha vontade imperialista russa de dominar as fontes e as linhas de abastecimento de petróleo e gás iranianos e da bacia do mar Cáspio, e, com isso, garantir uma influência forte sobre a vida econômica de seus adversários. O mapa da região conta a história toda. ${ }^{6}$ É por isso que Moscou não pode permitir a independência da Tchetchênia, não importa quantos morram para impor sua vontade. Ciente das ambições russas, os EUA estão encorajando uma alternativa às linhas de abastecimento que passam por Irã, Iraque e Rússia (SAFIRE, 1999). Pensar na possibilidade de interrupção do funcionamento destes oleodutos seria, em perspectiva, um golpe demasiado forte para a economia russa. Quiçá pensando nisso é que, ao final dos bombardeios no Kosovo, tropas russas ocuparam posições na região mesmo sem ser convidadas pelas forças aliadas da OTAN. Esse movimento russo forçou a aliança atlântica a abrir um espaço para que forças militares deste país também integrassem o contingente da força de paz que teriam a obrigação de preservar o equilíbrio político na região. Dessa maneira, mais de três mil militares russos formam parte das tropas de paz na região (LIDER opositor... 1999, p.A-15).

Quanto às relações entre Estados Unidos e Europa Ocidental dentro da aliança atlântica, nem mesmo a Europa Ocidental, que forma parte da OTAN, escapa a uma relação hierárquica diante dos Estados

\footnotetext{
'A Tchetchênia está 'sentada' sobre um dos oleodutos-chave que ligam a Rússia a um porto do mar Negro, passando pelo Bósforo, na Turquia, e chegando ao mar Mediterrâneo.
} 
Unidos. Como sustentado por Zbiniew Brzezinski, a posição da Europa é de quase subordinação e dependência, em relação aos Estados Unidos dentro da OTAN: Os Estados Unidos se manterá como o sócio dominante da Aliança Atlântica (OTAN) durante a primeira metade do século XXI. Nem uma maior integração política nem uma maior ampliação criarão a UE (União Européia) que alguns americanos desejam e alguns norte-americanos temem (...) Europa- apesar de sua fortaleza e sua significativa integração econômica e financeira e sua autenticidade da amizade atlântica -é, de fato, um protetorado militar dos Estados Unidos. A aliança entre Estados Unidos e Europa não é eqüitativa e também não é menos certo que a assimetria do poder entre ambos se acentuará ainda mais a favor dos Estados Unidos . (BRZEZINSKI, 2000, p.43-44)

No caso da Europa Ocidental, sua preocupação de fundo e conseqüente inserção no conflito estava relacionada com o problema da imigração de habitantes da região dos Bálcãs para as demais áreas da Europa. Durante o desenrolar do conflito do Kosovo mais de $800 \mathrm{mil}$ refugiados se concentraram nos campos de refugiados da Macedônia, os quais possivelmente teriam como objetivo, caso o conflito se prolongasse, migrar em direção a países como França, Alemanha, Inglaterra e Itália. Além da pressão sobre os mecanismos de previdência social, a pressão sobre empregos menos qualificados e a possibilidade de gerar problemas de segurança pública, existe o problema de ordem cultural, agravado pelo fato de que, enquanto a população nacional dos países da União Européia cresce a taxas aquém do que se pode considerar como normal, as populações migrantes árabe-muçulmanas injetam um padrão de crescimento populacional bastante alto, gerando desconfianças sobre a futura composição racial desta parte do velho continente $^{7}$. Deslocado para um sentimento antiárabe, isto explicaria o crescimento de movimentos e partidos nacionalistas xenófobos na Áustria, na Alemanha, na França e na Itália. Exemplo disso é o crescimento da Frente Nacional de Jean-Marie Le Pen na França, que de magros resultados eleitorais na década de 80 atingiu quase $17 \%$ do

\footnotetext{
${ }^{7}$ Segundo a ONU, o crescimento populacional ideal de um país deveria estar na ordem do $1 \%$, ou seja, uma taxa de fecundidade de aproximadamente dois filhos por casal. Enquanto isso as famílias muçulmanas crescem em proporção de quatro a seis filhos por casal.
} 
eleitorado indo ao segundo turno das eleições francesas em 2002 (HUNTINGTON, 1997).

No caso da China, mesmo que ela não agisse diretamente, também foi um ator relevante no conflito, pois sua situação é muito semelhante à da Iugoslávia. Isto porque ela possui o seu próprio Kosovo, ou seja, o Tibete. O Tibete encontra-se sob domínio da China desde 1950. Ultimamente as relações entre China e Tibete se apresentam num quadro de constante tensão. Daí segue o raciocínio que tenta explicar um dos motivos da China tomar a posição de não apoiar a intervenção da OTAN no conflito do Kosovo. O apoio da China nesta intervenção poderia, de certa forma, fazer com que houvesse efeitos ou projeções internas na sua problemática com o Tibete e se potencializarsse também uma futura ação das grandes potências, através de pressões sobre o país quanto à questão do Tibete e também de Taiwan. Frente aos interesses em preservar o Tibete e Taiwan, não é de se estranhar que a China tome esta posição; a disposição norte-americana de ir à guerra por princípios, antes do que por segurança, espanta a China. Beijing aparentemente contava com uma aliança militar ocidental baseada em interesses estratégicos concretos e não em princípios humanitários (OLIVEIRA,1999b, p.5).

Nem todos os estudos dedicados ao conflito do Kosovo são unânimes em sustentar uma posição estritamente realista. Numa posição muito próxima do idealismo, Viola e Leis apóiam-se na vitória dos globalisto-progressistas ${ }^{8}$ para sustentar que os ataques da OTAN à Iugoslávia foram corretos e justificáveis no sentido de defender os princípios humanitários e a governabilidade global democrática. Segundo essa visão, no ataque da OTAN à Iugoslávia não estavam em questão os defensores e agressores da soberania nacional, nem defensores e agressores dos direitos humanos, nem alianças étniconacionais históricas. Isto suporia uma tremenda redução da complexidade do conflito a questões importantes, porém menores. Neste ataque está sendo discutida a governabilidade dos Estados em um

\footnotetext{
${ }^{8}$ Os globalisto-progressistas defendem economias abertas ao mercado mundial, expansão publicamente regulada do direito de propriedade intelectual, fortalecimento do FMI, um papel central para as corporações transnacionais, reforma da ONU etc.
} 
mundo simultaneamente globalizado e fragmentado 9 e, por extensão, a governabilidade do próprio mundo globalizado em si mesmo. $\mathrm{O}$ essencial nesse episódio é a complexa e lenta emergência de um novo Direito Global Democrático Ocidental ${ }^{10}$ definitivamente hierarquizado sobre os Direitos Nacionais e sobre o Direito Internacional da ONU ${ }^{11}$, a partir de uma nova vinculação das normas do direito público democrático com o nascente Direito Global Democrático Ocidental (VIOLA; LEIS, 1999, p.11).

No entanto, esta visão é conflitante com a visão e o status dos direitos humanos de cidadãos e indivíduos que estão além das fronteiras nacionais. Na concepção realista da política e das relações internacionais, a soberania, que a matriz idealista, no plano ideológico, tenta enfraquecer, é uma característica de extrema importância ao Estado à medida que lhe confere autonomia e independência diante dos demais Estados no sistema internacional. Isto significa que nenhum outro interesse poderia sobrepor-se ao Estado, visto que compete a ele a realização das aspirações comuns de seu povo, bem como é sua responsabilidade a realização da concepção de bem comum de sua comunidade. Sua soberania e autonomia garantiam fundamentalmente o interesse nacional, e as decisões a serem tomadas (e mesmo uma eventual redução de sua autonomia) estariam centradas em algum interesse nacional (KRASNER apud OLIVEIRA, 1999a). Nessa perspectiva, o Estado e a comunidade política que representa não têm qualquer tipo de obrigação moral com outros Estados e com outros cidadãos que não sejam os seus. É por este motivo que a visão realista coloca em dúvida as justificativas ético-morais de uma decisão intervencionista.

Em artigo publicado durante o próprio desenvolvimento do conflito, Krasner afirma: "a crise no Kosovo é a última manifestação de

" (globalização segmentada ou "fragmigration")

10 Vigência de direitos humanos universais por cima das razões de Estado, democracia entendida como acesso ao poder político através da competição pluralista, vigência do Estado de Direito, direito de intervenção da comunidade internacional em Estados nacionais não-democráticos.

"Mínimo comum denominador acordado entre Estados soberanos que não estão obrigados a adotar o regime democrático de governabilidade e direito de veto das potências, inclusive das não-democráticas. 
uma longa história de intervenções externas nos Bálcãs envolvendo direitos de minorias. [Contudo] o peso das motivações para as intervenções tem mudado - a segurança era mais importante no século XIX e os assuntos humanitários no final do século XX" (KRASNER, 1999, p.2). Na verdade Krasner sugere que ninguém pode alarmar se diante de mais uma intervenção praticada pelas grandes potências na região. O que muda é a justificativa da intervenção.

Talvez a posição de Krasner(1999) seja um pouco radical, mas o que ele tenta deixar claro - com um argumento típico da teoria realista - é que intervenções feitas a partir de considerações ético-morais dificilmente adquirem êxito, visto que é o interesse nacional do Estado soberano que estabelece o que é certo e o que não é, o que pode e o que não pode dentro de seus limites internos. Direitos humanos e princípio de não-intervenção são, no mínimo, princípios concorrentes para os quais não existe uma estrutura internacional de autoridade. Dado que está ausente da autoridade internacional externa, a solução passa a ser quebrar o princípio de não-intervenção. Certamente a condição para que isso aconteça passa por ter o enfrentamento de dois poderosos Estados nacionais assimétricos quanto a suas capacidades de poder. É isso o que o próprio Krasner chama de hipocrisia organizada : em outras palavras, relações internacionais baseadas em capacidades de poder assimétricas admitem uma larga tolerância às exceções no comportamento das grandes potências mundiais, uma determinada teoria e uma retórica a respeito das dimensões do poder soberano (KRASNER apud TOSTES, 2000). Dito de outra maneira, trata-se de considerar os objetivos do Estado em coerência com uma ética secular, ou de amoralidade da política, que segue quase à risca a lógica maquiavélica dos fins objetivos contrariando uma lógica da ética nos assuntos públicos. Ou, como lembra Aron, a política compreende, por sua natureza, a dualidade amigo-inimigo e Estados [...] podem influenciar os países aliados [ou não aliados] no sentido desejável; mas não podem ir até o fundo da lógica do moralista [...]. Trata-se de uma questão de oportunidade, isto é, de prudência, e não de princípios, meter-se ou não nos negócios de outro país [...]. Nenhum 'monstro frio' obedece sempre aos direitos das gentes ou à moral (ARON, 1986, p.16-17). 
Adicionalmente, a intervenção contrariou os objetivos dos acordos de Dayton e as inúmeras resoluções do Conselho de Segurança sobre o conflito na Bósnia bem como as três resoluções que tratavam da crise no Kosovo que defendiam a soberania e a integridade territorial da Iugoslávia como condição sine qua non para o processo de paz. Há que se lembrar que Milosevic conseguiu, no acordo de Dayton de 1995, o reconhecimento internacional do novo Estado iugoslavo, não sendo condicionado à cláusula de respeito à minorias nem à devolução da autonomia do Kosovo. Essa permissividade dos Estados Unidos e da União Européia priorizava, como já foi realçado por Nogueira, a reconstrução do Estado iugoslavo como uma forma de atingir, no médio prazo, alguma estabilidade no delicado quadro político, estratégico e cultural dos Bálcãs. As justificativas da OTAN para a intervenção internacional no Kosovo basearam-se na crise humanitária engendrada pela repressão, pelos massacres e pela limpeza étnica da Bósnia entre 1992 e 1995. Isso contrariava o objetivo da reconstrução do Estado como maneira de atingir a estabilidade política da região. É muito possível que os membros da OTAN se tenham convencido de que essa reconstrução e, portanto, a estabilidade da região era impossível com Milosevic no poder, e que seria necessário sua derrubada para que aquele objetivo atingisse certa eficácia. Coerente com uma posição realista, essa hipótese explicaria, talvez de maneira mais correta, as verdadeiras motivações e objetivos da Aliança Atlântica.

Uma constatação importante a ressaltar é que, quanto à justificativa humanitária, logo que os Estados Unidos abandonaram, a partir da Segunda Guerra Mundial, sua postura isolacionista, é de praxe na sua política externa o intervencionismo aberto ou encoberto; da mesma forma, a visão de mundo enfocada no colonialismo ainda faz parte de uma boa parte das elites diplomáticas européias. Na opinião de Cavagnari, os bombardeios da OTAN contra a Iugoslávia formariam parte de um modelo que vem sendo testado [...] de certo modo, bem sucedido, desde a Guerra do Golfo, que é o da rendição incondicional. A característica desse modelo é o fechamento deliberado de todas as saídas para uma solução negociada depois de iniciado o conflito armado, visando resguardar 
o princípio da credibilidade. O jogo é de 'soma-zero'. (CAVAGNARI FILHO, 1999, p. 7) ${ }^{12}$.

\section{Considerações finais}

Diante das evidências, de acordo com a teoria realista, o componente humanitário da intervenção na Iugoslávia deve ter sido instrumentalizado por parte dos Estados Unidos e da Europa na perspectiva dos objetivos estratégicos já discutidos. Se é certo que parece demasiadamente cruel instrumentalizar os direitos humanos em face de objetivos latentes, a atitude da OTAN é sustentada como legítima e justificável por importantes pensadores do mundo contemporâneo, e, evidentemente, o pressuposto de fundo é que a ação deu-se por razões humanitárias. É o caso de Claude Leffort que tem levado esse raciocínio a um patamar explicativo quase absoluto, justificando inclusive a quebra do direito internacional por parte da OTAN resultante da não-consulta ao Conselho de Segurança da ONU: [...] não dizemos que a conduta dos Estados não é mais determinada em primeiro lugar pelos interesses de poder e seu lugar numa certa configuração de relações de força. Observemos somente que a sensibilidade coletiva aos direitos do homem é tal no presente que os dirigentes de um pequeno número de países foram obrigados a fazer uma guerra no coração da Europa contra um agressor cujo caminho era preciso barrar, mas também lá onde era possível limitá-lo. O direito internacional, como eu o disse, não autorizava isto. Era preciso transgredi-lo para defender seu princípio. Quem se espanta com isto não compreende que a lei requer sempre a ação de alguém, ou de alguns, que assume o risco de tornar-se sua garantia (LEFORT, 2000, p. 9-10).

\footnotetext{
12 Segundo Cavagnari, quando o jogo é de "soma-zero", não se impõem limites à ação militar desde que a política mantenha a intensidade da violência sob controle. Não se deve limitá-la, se nenhuma circunstância indique moderação e os meios disponíveis sejam suficientes para realizar o aniquilamento- isto é suficiente para romper a vontade do adversário de prosseguir na guerra. No caso de Kosovo, a oposição russa e chinesa foram insuficientes para forçar a moderação do conflito, ou para impedir que a OTAN impusesse seu diktat à Iugoslávia.
} 
Entretanto, tal hipótese humanitária, entra em confronto com as evidentes motivações de ordem político-estratégica. A OTAN e os Estados Unidos objetivavam submeter a Sérvia aos termos de Rambouillet e tinham o objetivo tácito de reduzir o protagonismo futuro da Rússia na Europa Oriental, garantindo assim a credibilidade futura da OTAN para intervir em possíveis conflitos na região. Mas esta tentativa não se restringia apenas à Europa Oriental. A organização, liderada pelos Estados Unidos, ao não se submeter aos vetos russo e chinês no Conselho de Segurança da ONU, objetivavam reduzir o protagonismo futuro da Rússia e da China no processo de decisão mundial através do enfraquecimento da ONU. Os Estados Unidos visavam, em longo prazo, projetar a OTAN como uma organização de grande poder e abrangência mundial. Em apoio a esta tese, é interessante citar o depoimento de um alto funcionário espanhol, que sob o pseudônimo de Vegetius escreveu, na edição espanhola da revista Foreign Affairs, uma crítica contundente a respeito da chamada hipótese humanitária do conflito: "não se tratava de resguardar os direitos básicos dos kosovar-albaneses nem do respeito à autonomia política da província, objetivos formais cujo papel não foi outro a não ser conquistar os corações das opiniões públicas ocidentais" (VEGETIUS, 1999, p.21-22).

Uma outra evidência, que talvez possa situar os direitos humanos num segundo plano na ação da Aliança Atlântica, foi a da reconstrução do Estado da Iugoslávia, e não a dos direitos humanos, na tentativa de atingir uma certa estabilidade política para a região. As declarações da OTAN apontavam para a intervenção com meio de deter o genocídio que o governo iugoslavo praticava contra a etnia albanesa-kosovar, mas no final do conflito o principal objetivo dos Estados Unidos era dissolver a ditadura de Milosevic na região e promover a democracia como valor universal, colocando a situação da população kosovaralbanesa em segundo plano. Em vez da ajuda humanitária à população albanesa-kosovar que voltava as suas casas faminta, com frio e ainda correndo o risco de encontrar suas casas destruídas por bombas da própria OTAN, o objetivo desta passou a ser a saída de Milosevic do poder na Iugoslávia. Após o conflito, a OTAN afastou-se do discurso humanitário, fazendo verdadeiras campanhas de caçada ao ditador e condicionando a ajuda financeira a esse objetivo. Assim, a saída de 
Milosevic do poder e a reconstrução e organização da Iugoslávia passaram a ser os principais objetivos das lideranças da OTAN na região. Alguns autores já têm alertado para o surgimento de um novo conceito estratégico no qual elementos valorativos universais como democracia e direitos humanos passam a desenvolver um papel na nova geopolítica do poder mundial: Ao fim da guerra fria, pouco depois da desintegração do bloco soviético, a Aliança Atlântica alterou sua razão de ser em busca de novas metas a partir da Declaração de Londres de julho de 1990. O 'novo conceito estratégico', aprovado em novembro de 1991, afirmou e se repetiu em 1999 como tarefa da Aliança 'o estabelecimento de um ordem justa, estável e pacífica na Europa, baseada nos valores comuns da democracia, nos direitos humanos e no império da lei (MIÑón, 1999, p. 58).

Estas conclusões vão na direção do que afirma Krasner, ou seja, de que as intervenções a partir de considerações ético-morais dificilmente adquirem êxito, pois, sendo subjetivas, visam certamente à instrumentalização político-estratégica de valores como direitos humanos e democracia. Kosovo é um exemplo entre outros. A intervenção humanitária promovida pela OTAN no Estado iugoslavo, antes de eliminar o genocídio e a limpeza étnica, provocou mais vítimas e sofrimento à população kosovar-albanesa. Com o uso exclusivo do poder aéreo, a OTAN errou vários alvos, atingindo a população que ela própria se comprometia a ajudar. Junto a isto, utilizava bombas de fragmentação - aquelas utilizadas para ferir o maior número de pessoas possível.. ${ }^{13} \mathrm{O}$ exemplo mais significante é o caso de Korisa (aldeia kosovar) onde em mais um dia de intensos bombardeios, a OTAN realizou o maior ataque com este tipo de bombas matando cem refugiados albaneses-kosovar e deixando mais de 50 feridos.

Como afirma Vegetius (1999, p.23): Para passar de uma legitimação de organismos de defesa coletiva a uma organização intervencionista, a Aliança sustenta o argumento da defesa dos direitos humanos. No Kosovo, todavia, a OTAN não fez mais que defender um conceito, porque não soube, com seus aviões, proteger as pessoas que só

\footnotetext{
${ }^{13}$ No ano de 1996, a Subcomissão da ONU para a Prevenção da Discriminação e Proteção das Minorias havia condenado o uso de bombas de fragmentação.
} 
encontraram refúgio em exílios. Ainda mais: a Aliança divulgou amplamente seu desejo de não deixar impunes os crimes contra a humanidade que teoricamente Milosevic estava cometendo em Kosovo. No entanto, em pouco esse objetivo ficaria vazio de conteúdo.

Se de fato houve algum componente humanitário na intervenção da OTAN na Iugoslávia, esta questão humanitária, como afirma a teoria realista, deve ter sido instrumentalizada por parte dos Estados Unidos e da Europa na perspectiva dos objetivos estratégicos. Se não há dúvidas de que instrumentalizar questões éticas, como justificativa para impor certos interesses, é despiedoso, seu altíssimo custo em termos de vidas humanas e de infra-estrutura também o é.

\section{Referências}

ALVES, J. A. L. Os direitos humanos em sursis . Lua Nova, São Paulo, n.35, $150-160,1995$.

ARON, R. Os últimos anos do século. Rio de Janeiro: Guanabara, 1986.

BEDIN, G. A. O realismo político e as relações internacionais: algumas reflexões sobre o paradigma tradicional das relações internacionais .

In: Paradigmas das relações internacionais. Ijuí: Unijuí, 2000.

BENEVIDES, M. V. Os direitos humanos como valor universal. Lua Nova, São Paulo, n.34, p.179-188, 1994.

BRZEZINSKI, Z. Vivir com una nueva Europa. Política Exterior, n.77 p.44-45, 2000.

CAVAGNARI FILHO, G. L. Anotações sobre a guerra de Kosovo. Carta internacional, São Paulo, ano 8, n.73, p.7, mar. 1999.

CHIAPPIN NOVAES, J. R. O paradigma de Huntington e o realismo político. Lua Nova, São Paulo, n.34, p.52-53, 1994.

CHOMSKY, N. A minoria próspera e a multidão inquienta. Brasília: Edunb, 1996.

GUIMARÃES, S. P. Quinhentos anos de periferia. Porto Alegre: Ed. UFRGS, 1999.

HUNTINGTON, S. P. O choque de civilizações e a recomposição da ordem mundial. Rio de Janeiro: Objetiva, 1997. 
KENNAN, G. A crise dos Bálcãs: 1913 e 1993. Política Externa, São Paulo, v. 2, n. 3, p. $70-84,1993$.

KRASNER, S. D. Contested Sovereignty. Carta Internacional, São Paulo, v.7, n.73, p.1-2, 1999.

LAFER, C. A soberania e os direitos humanos. Lua Nova, São Paulo, n.35, p.137-148, 1995.

LEFORT, C. O direito internacional, os direitos do homem e a ação política. Tempo Social, São Paulo, v.12, n.1, p.1-10, maio, 2000.

LÍDER opositor propõe greve geral contra Milosevic. O Estado de São Paulo, São Paulo, 7 jul.1999. p.15A.

MARIANO, K.; MARIANO, M. Uma interpretação do conceito de EstadoSubnacional à luz das teorias das relações internacionais. In: Gestão Pública estratégica de governos subnacionais frente aos processos de inserção internacional e integração latino-americana. São Paulo: FUNDAP, 1998.

MELlo, L. I. A. Quem tem medo da Geopolítica? São Paulo: Hucitec, 1999.

MIÑóN, M. Las guerras deben llegar a su fin. Errores de una pacificación impuesta. Política Exterior, São Paulo, n.71, p.15-22, set./out., 1999.

NOGUEIRA, J. P. A guerra do Kosovo e a desintegração da Iugoslávia: notas sobre a (re)construção do Estado no fim do milênio . Revista Brasileira de Ciências Sociais, São Paulo, v.15, n.44, p.141-60, out., 2000.

OLIVEIRA, H. A. A crise asiática e a parceria estratégica EUA-China . Carta Internacional, São Paulo, v.7, n.64, p.14, 1999a.

Bombardeios de embaixadas ou de uma parceria estratégica? Carta Internacional, São Paulo, v.7, n.76, p.5, 1999 b.

SAFIRE, W. Chechênia é vítima do Grande Jogo. Folha de São Paulo, São Paulo. 10 dez. 1999. p.1-14.

TOSTES, A. P. A hipocrisia que ronda a exclusão de atores externos na constituição da soberania de Westphalia. In: ENCONTRO DA ASSOCIAÇÃO BRASILEIRA DE CIÊNCIA POLÍTICA, 2., 2000, São Paulo.

VEGETIUS. Un año después de la guerra. Ganará la Alianza Atlántica la paz? Política Exterior, Madrid, n.75, p.21-22, mayo, 1999.

VIGEVANI, T. Realismo versus globalismo nas relações internacionais. Lua Nova, São Paulo, n.34, p.16, 1994. 
VILLA DUARTE, R. A. A OEA e a Globalização da política. In: ENCONTRO DA ASSOCIAÇÃO BRASILEIRA DE CIÊNCIA POLÍTICA, 2., 2000, São Paulo.

VIOLA, E; LEIS, H. Para além da Iugoslávia: expansão da democracia e da governabilidade global . Carta Internacional, São Paulo, v.7, n.73, p.9-11, 1999.

\section{Abstract}

This article remets Kosovo's war and humanitary question. It was intended to do a realistic reading about the interventions that OTAN had done to the soberan state of Iugoslavia early 1999. OTAN has used a discurs of protection of the human rights of the albanesa-kosovar population that was suffering process of etnical cleaning promoved by Slobodan Milosevic's government. The main objective of this article is to show, through this conflict example, how the principles about human rights can be sed like instruments that hide the important search of others kinds of polical-strategical motives and interests.

Key words: Kosovo, OTAN, human rigths, intervention 